\title{
Kinetics of digestion of low-quality forage grazed by beef cattle fed supplements containing increasing levels of rumen undegradable protein
}

\author{
Raphael dos Santos Gomes', Tadeu Silva de Oliveira1, José Carlos Pereira², Ricardo Augusto \\ Mendonça Vieira ${ }^{3}$, Cássio José da Silva ${ }^{4}$, Fernando de Paula Leonel ${ }^{5}$, Alberto Magno \\ Fernandes $^{3}$, Flavio Henrique Vidal Azevedo ${ }^{1}$
}

\footnotetext{
${ }^{1}$ Universidade Estadual do Norte Fluminense Darcy Ribeiro, Programa de Pós-graduação em Ciência Animal, Campos dos Goytacazes, RJ, Brazil. ${ }^{2}$ Universidade Federal de Viçosa, Departamento de Zootecnia, Viçosa, MG, Brazil.

${ }^{3}$ Universidade Estadual do Norte Fluminense Darcy Ribeiro, Laboratório de Zootecnia, Campos dos Goytacazes, RJ, Brazil.

${ }^{4}$ Universidade de Brasilia, Faculdade de Agronomia e Medicina Veterinária, Brasília, DF, Brazil.

${ }^{5}$ Universidade Federal de São João del Rei, Departamento de Zootecnia, São João del Rei, MG, Brazil.
}

\begin{abstract}
This experiment was conducted to evaluate the degradation kinetics and microbial efficiency of beef cattle grazing on low-quality forage and receiving supplements with different levels of rumen undegradable protein (RUP). The animals grazed on palisade grass pasture solely or this pasture and supplement containing 40 or $60 \mathrm{~g}$ of RUP per $100 \mathrm{~g}$ of crude protein $(\mathrm{CP})$. The degradation profiles of neutral detergent fiber, fiber carbohydrates, and neutral detergent insoluble protein were interpreted kinetically by using a decreasing logistic model. Treatments (no supplement, or RUP at 40 or $60 \mathrm{~g}^{-1} 100 \mathrm{~g} \mathrm{CP}$ ) did not affect rumen fill; however, the increase in the indigestible fiber carbohydrate fraction that occurred at the expense of the digestible fiber carbohydrate fraction resulted in a greater rumen fill effect. The palisade grass showed a significant proportion of its nitrogen in the form of slowly degradable protein as neutral detergent insoluble protein, which amounted to $26 \mathrm{~g}$ per $100 \mathrm{~g}$ CP. Supplementation with $40 \mathrm{~g}$ of RUP per $100 \mathrm{~g} \mathrm{CP}$ decresead the indigestible fraction of the low-quality forage. However, the absence of a rumen-fill effect demonstrates that the additional supply of nutrients contributes greatly to increasing growth efficiency and use of the available energy from the forage by the ruminal microorganisms.
\end{abstract}

Key Words: degradable protein, palisade grass, supplementation

\section{Introduction}

The modern nutrition systems for ruminants use the amino acid supply from digested and absorbed true proteins in the small intestine (Miranda et al., 2012; Gao et al., 2015). Tropical grasses have high herbage production, but as the forage matures, the cell walls become thick and incrusted by lignin. These alterations are constraints for microbial digestion and fermentation and decrease forage quality (Wilson, 1994; Wilson and Mertens, 1995). When cattle graze tropical grasses, most part of the energy derives from the potentially digestible fraction of fibrous carbohydrates. In these conditions, the largest part of crude protein that escapes ruminal degradation is associated with the insoluble residue, and this situation probably generates a deficit of rumen ammonia-N under both rainy

$\overline{\text { Received February 22, } 2016}$ and accepted June 2, 2016

Corresponding author: ramvieira@uenf.br

http://dx.doi.org/10.1590/S1806-92902016000900009

Copyright (C 2016 Sociedade Brasileira de Zootecnia. This is an Open Access article distributed under the terms of the Creative Commons Attribution License (http://creativecommons.org/licenses/by/4.0/), which permits unrestricted use, distribution, and reproduction in any medium, provided the original work is properly cited. and drought situations (Vieira et al., 2000a,b,c). Studies demonstrate that diets containing high protein levels do not increase the response of productive functions because of the lack of synchronism between protein and carbohydrate availability in the rumen and due to amino acid imbalances (Chiou et al., 1995; Harstad and Prestløkken, 2001; Gao et al., 2015). Besides, the prediction of metabolizable protein is most sensitive to digestion rates of protein fractions, and the laboratory analysis of the available forages and feeds used in the production system is the recommended approach to characterize feed resources. In the CNCPS, the metabolizable protein depends on digestion and passage rates and fractions such as soluble protein, ammonia, neutral detergent insoluble protein, and acid detergent insoluble protein (Higgs et al., 2015). Highly degradable true protein sources improve energy and amino acid supplies for ruminants grazing tropical forages, but their presence in the diet increases $\mathrm{N}$ excretion (Hentz et al., 2012). The highly available NPN and N compounds of rapid rumen degradation result in peaks of ammonia concentration in the rumen much before the peak of fermentation of the potentially digestible fraction of fibrous carbohydrates (Van Soest, 1994; Russell, 2002). Because cattle farming 
in tropical regions is mostly based on the use of pastures, supplementation with rumen undegradable protein is expected to provide better use of fibrous carbohydrates and increase animal performance.

Our goal was to evaluate the degradation kinetics and indirect microbial growth in steers grazing on low-quality forage and receiving supplements with different levels of rumen undegradable protein.

\section{Material and Methods}

The experiment was conducted in the central plateau of Goiás State, Brazil, and its climate is a Cwa type according to Köppen standards (Kottek et al., 2006). The average annual temperature is $22{ }^{\circ} \mathrm{C}$, varying by five degrees throughout the year, on average, and the average annual precipitation $(1,450 \mathrm{~mm})$ is characterized by a periodical distribution of two well-defined seasons, with a greater concentration of rains occurring in the period from November to March, i.e., the rainy season (Table 1). The experiment was conducted from March to May and was divided into three periods of 22 days ( 15 days for adaptation of animals and seven days for sample collection). Periods 1, 2, and 3 occurred during March, April and May, respectively. Nine esophagus- and rumen-cannulated crossbred steers were used in the experiment to evaluate the degradation kinetics of the extrusa nutrients. The animals grazed on a rotational palisade grass pasture cultivated as "Sistema Barreirão" (Oliveira et al., 1996), where they received the following experimental treatments: $\mathrm{T}_{0}$ (pasture only), $\mathrm{T}_{40}$ (pasture + supplement with $40 \mathrm{~g}$ of RUP per $100 \mathrm{~g}$ of $\mathrm{CP}$ ), and $\mathrm{T}_{60}$ (pasture + supplement with $60 \mathrm{~g}$ of RUP per $100 \mathrm{~g}$ of CP). A mineral mixture was available ad libitum to the animals during the three periods. The formulation and amount of the supplements fed to the animals (Table 2) and the chemical composition of supplements, pasture (by hand picking), and extrusa samples are fully described (Table 3 ).

Esophageal extrusa samples were collected in the morning for seven days into nylon bags with plastic-screen at the bottom to drain excess saliva (Scales et al., 1974; Vieira et al., 2000a). The nylon bags were adapted to provide flexibility and comfort to the animals during grazing. The extrusa was collected after a previous fasting period of

Table 1 - Maximum and minimum average temperature and rainfall in the experimental period

\begin{tabular}{lccc}
\hline Period & Maximum $\left({ }^{\circ} \mathrm{C}\right)$ & Minimum $\left({ }^{\circ} \mathrm{C}\right)$ & Rainfall $(\mathrm{mm})$ \\
\hline 1 & 26.7 & 17.4 & 532.9 \\
2 & 28.5 & 16.9 & 132.6 \\
3 & 26.8 & 14.8 & 158.5 \\
\hline
\end{tabular}

approximately $16 \mathrm{~h}$. The sampling period lasted $30 \mathrm{~min}_{\text {day }}{ }^{-1}$. After each extrusa collection, samples were properly stored at $-20{ }^{\circ} \mathrm{C}$. Samples were then dried at $55^{\circ} \mathrm{C}$ in a forcedair oven. Analyses of crude protein (CP), crude fat (CF), and ash followed the recommendations by AOAC (1990). Neutral detergent insoluble protein (NDIP) was obtained according to the standard procedure given by Licitra et al. (1996). The content of neutral detergent fiber (NDF) was assessed according to the procedure described by Van Soest et al. (1991), without amylase and sodium sulfite additions. The content of fibrous carbohydrates (FC) was obtained by discounting the NDIP and ash contents from the fiber residue (Sniffen et al., 1992). Total carbohydrates (TC) and non-fibrous carbohydrates (NFC) were estimated according to Sniffen et al. (1992): TC (g/kg DM) $=1000-C P-C F-a s h$, and $\mathrm{NFC}=\mathrm{TC}-\mathrm{FC}$. Lignin was assumed as an integral part of the unavailable FC, i.e., the indigestible carbohydrate fraction.

Table 2 - Formulation and supplied quantity of supplements

\begin{tabular}{|c|c|c|}
\hline \multirow{2}{*}{ Ingredient } & \multicolumn{2}{|c|}{ Supplement } \\
\hline & $\mathrm{T}_{40}$ & $\mathrm{~T}_{60}$ \\
\hline Corn meal $^{1}$ & 476 & 890 \\
\hline Corn gluten ${ }^{1}$ & 0 & 108 \\
\hline Corn germ ${ }^{1}$ & 376 & 0 \\
\hline Soybean meal ${ }^{1}$ & 62 & 0 \\
\hline Wheat bran ${ }^{1}$ & 84 & 0 \\
\hline Urea $^{1}$ & 2 & 0 \\
\hline Amount supplied ${ }^{2}$ & 1,780 & 1,800 \\
\hline
\end{tabular}

Table 3 - Mean values for the chemical components of supplements and Palisade grass pasture

\begin{tabular}{|c|c|c|c|c|c|c|}
\hline \multirow{2}{*}{ Nutrient } & \multirow{2}{*}{ Pasture } & \multicolumn{3}{|c|}{ Extrusa sample } & \multicolumn{2}{|c|}{ Supplement } \\
\hline & & $\mathrm{P} 1$ & $\mathrm{P} 2$ & P3 & $\mathrm{T}_{40}$ & $\mathrm{~T}_{60}$ \\
\hline $\mathrm{CP}^{1}$ & 73 & 147 & 94 & 76 & 150 & 169 \\
\hline NDIP $^{1}$ & 4 & 9 & 5 & 4 & 16 & 10 \\
\hline $\mathrm{EE}$ & 12 & 19 & 16 & 13 & 38 & 35 \\
\hline $\mathrm{MM}^{1}$ & 75 & 111 & 132 & 131 & 28 & 13 \\
\hline $\mathrm{NDF}^{1}$ & 792 & 675 & 679 & 725 & 178 & 109 \\
\hline $\mathrm{TC}^{1}$ & 862 & 723 & 757 & 780 & 786 & 782 \\
\hline $\mathrm{FC}^{1}$ & 768 & 600 & 628 & 679 & 157 & 97 \\
\hline $\mathrm{NFC}^{1}$ & 80 & 123 & 129 & 101 & 629 & 685 \\
\hline $\mathrm{RDP}^{2}$ & - & - & - & - & 360 & 288 \\
\hline RUP $^{2}$ & - & - & - & - & 640 & 712 \\
\hline
\end{tabular}

$\mathrm{P} 1, \mathrm{P} 2$, and $\mathrm{P} 3$ - periods 1,2 , and 3, respectively; $\mathrm{T}_{40}$ - supplement with $40 \mathrm{~g}$ rumen undegradable protein per $100 \mathrm{~g}$ of crude protein; $\mathrm{T}_{60}$ - supplement with $60 \mathrm{~g}$ rumen undegradable protein per $100 \mathrm{~g}$ of crude protein.

CP - crude protein; NDIP - neutral detergent insoluble protein; EE - ether extract; MM - mineral matter; NDF - neutral detergent fiber; TC - total carbohydrates; FC - fiber carbohydrates; NFC - non-fiber carbohydrates; RDP - rumen degradable protein; RUP - rumen undegradable protein.

${ }^{1} \mathrm{~g} \mathrm{~kg}^{-1} \mathrm{DM}$.

$2 \mathrm{~g} \mathrm{~kg}^{-1} \mathrm{CP}$. 
The in situ degradability of NDF, FC, and NDIP of extrusa samples was determined according to the technique described by (Nocek, 1988). Nylon bags $(14 \mathrm{~cm} \times 7 \mathrm{~cm}$, pore diameter $50 \mu \mathrm{m}$ ) were used to keep a sample DM to bag useful surface ratio of $20 \mathrm{mg} \mathrm{cm}^{-2}$. Approximately $2 \mathrm{~g}$ of dried extrusa samples ground through a 5-mm mesh sieve were used at each incubation time. Three animals per treatment and per period were used and the extrusa samples were incubated for 3, 6, 9, 12, 24, 36, 72, and $96 \mathrm{~h}$, without blank correction.

The undigested residuals of the incubation trials were analyzed for NDF, FC, and NDIP as previously described. The decreasing logistic model proposed by Van Milgen et al. (1991) was fitted to the degradation profiles generated:

$R(t)=A(c \exp (-p t)-p \exp (-c t)) /(c-p)+I+e_{i} \quad$ Eq. (1),

in which $\mathrm{R}(\mathrm{t})\left(\mathrm{g} \mathrm{kg}^{-1} \mathrm{DM}\right)$ is the incubation residue at a given time, $\mathrm{t}(\mathrm{h}) ; \mathrm{A}\left(\mathrm{g} \mathrm{kg}^{-1} \mathrm{DM}\right)$ is the insoluble but potentially degradable fraction until the end of the lag period, which becomes gradually available at the fractional rate $\mathrm{p}\left(\mathrm{h}^{-1}\right)$, which is degraded, in sequence, at the fractional rate $\mathrm{c}\left(\mathrm{h}^{-1}\right) ; \mathrm{I}\left(\mathrm{g} \mathrm{kg}^{-1} \mathrm{DM}\right)$ is the indigestible or unavailable fraction, which no longer changes over time by microbial activity, i.e., when $t \rightarrow \infty$. The error term is $e_{i}$, assumed normally, uniformly and independently distributed with mean zero and variance $\sigma^{2}$. In situations where $p$ tended to $c$, the model was reparameterized by applying L'Hôpital's rule, generating the alternative equation described by Van Milgen et al. (1991):

$R(t)=A(1+\lambda t) \exp (-\lambda t)+I+e_{i}$

Eq. (2),

in which $\lambda$ is the fractional degradation rate $\left(\mathrm{h}^{-1}\right)$ when $p$ tends to $c$. Parameters A, I, c, and p of Eq. (1) or parameters of Eq. (2) were estimated using the Marquardt algorithm of PROC NLIN of SAS (Statistical Analysis System, version 9.0).

The indigestible neutral detergent fiber (iNDF), digestible fibrous carbohydrates ( $\mathrm{dFC}$ ), indigestible fibrous carbohydrates (iFC), digestible neutral detergent insoluble protein (dNDIP), and indigestible neutral detergent insoluble protein (iNDIP), expressed in $\mathrm{g} \mathrm{kg}^{-1} \mathrm{DM}$, were estimated according to the following equations:

$$
\begin{aligned}
& i N D F=I_{p} \times N D F \\
& d F C=A_{p} \times F C \\
& i F C=I_{p} \times F C \\
& d N D I P=A_{p} \times N D I P \\
& i N D I P=I_{p} \times N D I P
\end{aligned}
$$

which $\mathrm{A}_{\mathrm{p}}$ and $\mathrm{I}_{\mathrm{p}}$ are the standardized estimates $\hat{A} /(\hat{A}+\hat{I})$ and $\hat{I} /(\hat{A}+\hat{I})$, respectively (Waldo et al., 1972; Vieira et al., 1997).
We treated part of the extrusa samples with neutral detergent and chromium dichromate according to the procedures presented by Udén et al. (1980). The marked samples were directly added to the dorsal rumen via cannula and fecal grab samples taken to form fecal marker excretion profiles. Pereira et al. (2005) interpreted kinetically the marker excretion profiles to yield the estimates of the passage rate parameter estimates $(N, \lambda$, and $k)$ that were used as inputs to compute the average passage rate or $k_{p}$ used in the present study. The effective ruminal degradability (RD) of $\mathrm{dFC}$ and of dNDIP were estimated by the reciprocal function of Eq. (1) as described by Vieira et al. (1997) and defined by the following expressions:

$$
R D(d F C)=d F C \times c p /\left(\left(c+k_{p}\right)\left(p+k_{P}\right)\right)
$$

$R D(d N D I P)=d N D I P \times c p /\left(\left(c+k_{p}\right)\left(p+k_{p}\right)\right)$

in which $\mathrm{k}_{\mathrm{p}}\left(\mathrm{h}^{-1}\right)$ is the average passage rate of the digesta through the ruminoreticulum according to the following expression: $\mathrm{k}_{\mathrm{p}}=1 / \mathrm{MRT}$, in which MRT (mean retention time in the ruminoreticulum), was obtained as follows:

$\operatorname{MRT}(h)=N / \lambda+1 / k$

$\mathrm{N}$ is the order of time dependency of the gamma function (Pond et al., 1988).

The total and partial rumen-fill (RF) effects of the potentially degradable $(R F(D))$ and indigestible $(R F(I))$ fiber fractions were calculated based on the standardized estimates of parameters $A_{p}$ and $I_{p}$. According to Vieira et al. (1997), the RF can be described by Eq. (11):

$R F=A_{p}\left(c+p+k_{p}\right) /\left(\left(c+k_{p}\right)\left(p+k_{p}\right)\right)+I_{p} / k_{p}$

in which RF is total rumen-fill effect, expressed in hours (h). The first term of the previous equation corresponds to the level of rumen fill of the potentially degradable fraction, while the second represents the indigestible fraction.

Following the same reparameterization reasoning of $\mathrm{R}(\mathrm{t})$, i.e., when $p$ tends to $c$, the calculations referring to $\mathrm{RD}$ and RF were obtained by the following expressions (Vieira et al., 1997):

$$
\begin{aligned}
& R D(d F C)=d F C \times \lambda^{2} /\left(\lambda+k_{p}\right)^{2} \\
& R D(d N D I P)=d N D I P \times \lambda^{2} /\left(\lambda+k_{p}\right)^{2} \\
& R F=A_{P}\left(2 \lambda+k_{p}\right) /\left(\lambda+k_{p}\right)^{2}+I_{p} / k_{p}
\end{aligned}
$$

Assuming that the amount of dry matter that disappears in the rumen is directly proportional to the microbial mass formed, the microorganism growth rate can be estimated from the substrate intake. In this sense, the specific growth rate of the microorganisms on $\mathrm{dFC}$ was estimated according to the expressions described by Van Milgen et al. (1991), 
Vieira et al. (1997), and Vieira et al. (2000b). Thus, by employing the definition of Schofield et al. (1994), we have:

$S G R=c p(\exp (p(\ln p-\ln c) /(c-p))-\exp (c(\ln p-\ln c) /(c-p))) /(c-p)$

Eq. (15),

in which $S G R\left(\mathrm{~h}^{-1}\right)$ corresponds to the specific growth rate of the microorganisms on fraction dFC. In the cases in which $p$ estimates tended to $c$, we applied L'Hôpital's rule on Eq. (15) to yield Eq. (16) to obtain the maximum growth rate of the microorganisms on $\mathrm{dFC}$ fractions.

$S G R=\lambda \exp (-1)$

Parameter $\lambda$ corresponds to the fractional growth rate of microorganisms on $\mathrm{dFC}$, also expressed as $\mathrm{h}^{-1}$.

Variables iNDF, RF, RF(D), RF(I), dFC, iFC, RD(dFC), SGR dNDIP, iNDIP, and RD(dNDIP) were evaluated for the dispersion of data and scaled to body mass according to the model suggested by Brody (1945) and by Kleiber (1975), defined by the equation below:

$Y_{i j k}=\alpha M_{i j k}^{\beta}+e_{i j k}$

Eq. (17),

in which $Y_{i j k}$ is the dependent variable; $\alpha>0$ is an inherent constant of the model; $\beta$ is the scaling parameter between dependent and independent variables; $M_{i j k}$ is the body mass of each animal $k$ according to period $j$ and supplement $i$; and $e_{i j k}$ is the random error. The decision whether or not to correct the dependent variable was made considering the following hypotheses: $H_{0}: \beta=0$ and $H_{a}: \beta \neq 0$. The model was considered satisfactorily fitted to data whenever the asymptotic $95 \%$ confidence intervals for $\beta$ obtained using the SAS software (Statistical Analysis System, version 9.0) did not contain the zero value (rejection of $\mathrm{H}_{\mathrm{o}}$ ). We obtained the scaled mass as the dependent variable as follows:

$Y_{i j k}($ scaled $)=Y_{i j k} / M_{i j k}^{\widehat{\beta}}$

The data corresponding to the previously described variables were analyzed in a completely randomized design in a factorial arrangement, considering the added RUP level $\left(\alpha_{i}\right)$ and the period $\left(\tau_{k}\right)$ as the main factors and their interaction (Gill, 1986). The studied variables were interpreted statistically by analysis of variance and regression. The basic statistical model was:

$$
Y_{i j k} \text { or } Y_{i j k}(\text { scaled })=\mu+\alpha_{i}+a_{j(i)}+\tau_{k}+\alpha \tau_{i k}+e_{i j k}
$$

in which $\mu$ is a constant, $a_{j(i)}$ is the nested effect of animal for each RUP level, and $e_{i j k}$ was assumed Normal $\left(0, \sigma^{2}\right)$. For the quantitative factor (treatment), the models were chosen based on the significance of the regression coefficients, using the F test at a probability level of 0.05 , whereas for the qualitative factor (period), the means were compared by Tukey's test by adopting 0.05 of probability. Additionally, t-statistics was used to build confidence intervals for the regression coefficients considering the confidence level of 0.95 . The degrees of freedom of the denominator were computed accordingly (Satterthwaite, 1946; Gill, 1986).

\section{Results}

An interaction effect was detected between the RUP levels and periods for iNDF, RF, and RF(D) (Table 4).

Table 4 - Mean values for the degradation kinetics of neutral detergent fiber

\begin{tabular}{|c|c|c|c|c|c|c|c|}
\hline \multirow{2}{*}{ Period } & \multicolumn{3}{|c|}{ Treatment } & \multirow{2}{*}{ Equation } & \multicolumn{3}{|c|}{$\mathrm{CI}\left(\beta_{\mathrm{i}}\right) 0.95$} \\
\hline & $\mathrm{T}_{0}$ & $\mathrm{~T}_{40}$ & $\mathrm{~T}_{60}$ & & $\beta_{0}$ & $\beta_{1}$ & $\beta_{2}$ \\
\hline \multicolumn{8}{|l|}{ iNDF } \\
\hline 1 & $109 \mathrm{c}$ & $118 \mathrm{c}$ & $133 b$ & $\hat{\mathrm{Y}}=120$ & $(110 ; 130)$ & - & - \\
\hline 2 & $192 b$ & $195 b$ & $223 a$ & $\hat{\mathrm{Y}}=189+0.45 \mathrm{X}$ & $(172 ; 205)$ & $(0.04 ; 0.85)$ & - \\
\hline 3 & $231 \mathrm{a}$ & $248 \mathrm{a}$ & $212 \mathrm{a}$ & $\hat{\mathrm{Y}}=231+1.97 \mathrm{X}-3.8 \times 10^{-2} \mathrm{X}^{2}$ & $(213 ; 248)$ & $(0.36 ; 3.58)$ & $\left(-6.5 \times 10^{-2} ;-1.1 \times 10^{-2}\right)$ \\
\hline \multicolumn{8}{|l|}{ RF } \\
\hline 1 & $19.04 b$ & $23.33 b$ & $23.69 \mathrm{~b}$ & $\hat{Y}=19.30+0.08 X$ & $(15.91 ; 22.69)$ & $\left(2.7 \times 10^{-4} ; 1.6 \times 10^{-1}\right)$ & - \\
\hline 2 & $31.07 \mathrm{a}$ & $25.27 b$ & $34.33 \mathrm{a}$ & $\hat{Y}=31.07-0.54 X-1.0 \times 10^{-2} X^{2}$ & $(27.55 ; 34.59)$ & $(-0.87 ;-0.22)$ & $\left(4.5 \times 10^{-3} ; 1.5 \times 10^{-2}\right)$ \\
\hline 3 & $31.28 \mathrm{a}$ & $31.58 \mathrm{a}$ & $30.36 \mathrm{a}$ & $\hat{\mathrm{Y}}=31.07$ & $(29.04 ; 33.11)$ & - & - \\
\hline \multicolumn{8}{|l|}{$\mathrm{RF}(\mathrm{D})$} \\
\hline 1 & $10.08 b$ & $13.93 \mathrm{a}$ & $11.82 \mathrm{a}$ & $\hat{\mathrm{Y}}=10.08+0.23 \mathrm{X}-3.4 \times 10^{-3} \mathrm{X}^{2}$ & $(8.22 ; 11.95)$ & $(0.06 ; 0.40)$ & $\left(-6.3 \times 10^{-3} ;-4.5 \times 10^{-4}\right)$ \\
\hline 2 & $12.05 \mathrm{a}$ & $10.53 \mathrm{c}$ & $11.87 \mathrm{a}$ & $\hat{\mathrm{Y}}=11.48$ & $(10.41 ; 12.56)$ & - & - \\
\hline 3 & $12.85 \mathrm{a}$ & $12.26 \mathrm{~b}$ & $12.23 \mathrm{a}$ & $\hat{\mathrm{Y}}=12.45$ & $(11.37 ; 13.52)$ & - & - \\
\hline \multicolumn{8}{|l|}{$\mathrm{RF}(\mathrm{I})$} \\
\hline 1 & & $10.08 \mathrm{~b}$ & & & - & - & - \\
\hline 2 & & $18.74 \mathrm{a}$ & & $\hat{\mathrm{Y}}=15.82$ & $(13.86 ; 17.77)$ & - & - \\
\hline 3 & & $18.63 a$ & & & - & - & - \\
\hline
\end{tabular}

$\mathrm{T}_{0}$ - pasture only; $\mathrm{T}_{40}$ - supplement with $40 \mathrm{~g}$ rumen undegradable protein per $100 \mathrm{~g}$ of crude protein; $\mathrm{T}_{60}$ - supplement with $60 \mathrm{~g}$ rumen undegradable protein per $100 \mathrm{~g}$ of crude protein; CI - confidence interval.

Means followed by different letters in the column differ by Tukey's test $(\mathrm{P}<0.05)$.

iNDF - indigestible neutral detergent fiber, $\mathrm{g} \mathrm{kg}^{-1} \mathrm{DM}$; RF - rumen fill, h; RF(D) - rumen-fill effect of the potentially degradable fiber, h; RF(I) - rumen-fill effect of the indigestible fiber, h. 
The indigestible NDF increased linearly in period two, and showed quadratic response in period three, with an estimated maximum value of $257 \mathrm{~g} \mathrm{~kg}^{-1} \mathrm{DM}$, corresponding to the RUP level of $25.92 \%$, and no treatment effect was observed in period one. Rumen fill had a linear increase in period one, and a quadratic response in period two, with a minimum value of $24 \mathrm{~h}$ that corresponded to $27 \%$ RUP. No influence of RUP supplementation on RF was detected in period three. A quadratic response was found for variable $\mathrm{RF}(\mathrm{D})$ in period one, with a maximum value of $14 \mathrm{~h}$ at the RUP level of $33.82 \%$. The interaction effect did not influence the rumen fill of the indigestible fraction $(\mathrm{RF}(\mathrm{I}))$; neither RUP level exerted an effect on RF(I). Nevertheless, periods affected the RF(I) and the lowest rumen fill occurred at period one. There were differences between the periods within each level of RUP for variables iNDF, RF, and RF(D), with lowest values found in period one, except for $\mathrm{T}_{40}$, in which the opposite occurred for RF(D) (Table 4).

An interaction effect was found between the RUP levels and the periods for indigestible (iFC) and digestible fiber carbohydrates (dFC) (Table 5). The indigestible FC, or carbohydrate fraction $\mathrm{C}$, had a quadratic response in periods one and two, with minimum values of 85 and $132 \mathrm{~g} \mathrm{~kg}^{-1} \mathrm{DM}$ that corresponded to the RUP levels of 27.14 and $24.13 \%$, respectively; whereas a linear decrease occurred in period three. In the case of periods within each level of RUP, period three was superior to the others (Table 5). The digestible FC, or carbohydrate fraction $\mathrm{B}_{2}$, decreased linearly in period two, and had quadratic response in period three, with a minimum of $466 \mathrm{~g} \mathrm{~kg}^{-1} \mathrm{DM}$ at $21.87 \%$ of RUP. This variable was not influenced by the treatments in period one. For periods within each RUP level, there was no significant differences between periods one and two for $\mathrm{T}_{0}$, whereas period one had higher values than period two at $\mathrm{T}_{40}$ and $\mathrm{T}_{60}$ (Table 5). The RUP levels did not influence the specific growth rate on fibrous carbohydrates, and the ruminal degradability of $\mathrm{dFC}$ was equally not affected (Table 5).

There was an interaction effect between the RUP levels and periods for variables iNDIP, dNDIP, and RD (dNDIP). The indigestible NDIP, or iNDIP fraction, showed a quadratic response in period one, with a minimum value of $4 \mathrm{~g} \mathrm{~kg}^{-1} \mathrm{DM}$ at the RUP level of $30.17 \%$; no effect of RUP levels was observed in periods two and three. In terms of periods within each level of RUP, the iNDIP of $\mathrm{T}_{40}$ of period one was lower than the others, whereas no differences were observed between periods for $\mathrm{T}_{0}$ and $\mathrm{T}_{60}$ (Table 6). The digestible NDIP, or protein fraction $\mathrm{B}_{3}$, presented a quadratic response in period one and two, with a minimum value of $41 \mathrm{~g} \mathrm{~kg}^{-1} \mathrm{DM}$ and a maximum of $24 \mathrm{~g} \mathrm{~kg}^{-1} \mathrm{DM}$ in period two, at RUP levels of 34.17 and $25.40 \%$, respectively. No treatment effects in period three were observed. There was a significant difference between periods for all treatments, and the extrusa presented the highest dNDIP values during period one. The ruminal degradability of dNDIP showed a quadratic response in period one, with a minimum value of $21 \mathrm{~g} \mathrm{~kg}^{-1} \mathrm{DM}$ at the RUP value of $31.25 \%$. No influence of treatments occurred during periods two and three. The $\mathrm{RD}(\mathrm{dNDIP})$ was higher at the first period for all treatments (Table 6).

Table 5 - Mean values for the degradation kinetics of fiber carbohydrates

\begin{tabular}{|c|c|c|c|c|c|c|c|}
\hline \multirow{2}{*}{ Period } & \multicolumn{3}{|c|}{ Treatment } & \multirow{2}{*}{ Equation } & \multicolumn{3}{|c|}{$\mathrm{CI}\left(\beta_{\mathrm{i}}\right) 0.95$} \\
\hline & $\mathrm{T}_{0}$ & $\mathrm{~T}_{40}$ & $\mathrm{~T}_{60}$ & & $\beta_{0}$ & $\beta_{1}$ & $\beta_{2}$ \\
\hline \multicolumn{8}{|l|}{$\overline{\mathrm{iFC}}$} \\
\hline 1 & $106 \mathrm{c}$ & $89 \mathrm{c}$ & $114 b$ & $\hat{Y}=106-1.52 X+2.8 \times 10^{-2} X^{2}$ & $(91 ; 121)$ & $(-2.91 ;-0.14)$ & $\left(4.1 \times 10^{-3} ; 5.1 \times 10^{-2}\right)$ \\
\hline 3 & $212 \mathrm{a}$ & $182 \mathrm{a}$ & $190 \mathrm{a}$ & $\hat{\mathrm{Y}}=208-0.41 \mathrm{X}$ & $(194 ; 223)$ & $(-0.76 ;-0.06)$ & - \\
\hline \multicolumn{8}{|l|}{$\mathrm{dFC}$} \\
\hline 3 & $477 b$ & $474 \mathrm{ab}$ & $501 \mathrm{a}$ & $\hat{Y}=477-1.05 X+2.4 \times 10^{-2} X^{2}$ & $(462 ; 492)$ & $(-2.43 ; 0.33)$ & $\left(8.0 \times 10^{-4} ; 4.8 \times 10^{-2}\right)$ \\
\hline \multicolumn{8}{|l|}{ SGR } \\
\hline \multirow{2}{*}{\multicolumn{7}{|c|}{$(0.0327 ; 0.0497)$}} & - \\
\hline & & & & & & & - \\
\hline
\end{tabular}

$\mathrm{T}_{0}$ - pasture only; $\mathrm{T}_{40}$ - supplement with $40 \mathrm{~g}$ rumen undegradable protein per $100 \mathrm{~g}$ of crude protein; $\mathrm{T}_{60}$ - supplement with $60 \mathrm{~g}$ rumen undegradable protein per $100 \mathrm{~g}$ of crude protein; CI - confidence interval.

Means followed by different letters in the column differ by Tukey's test $(\mathrm{P}<0.05)$.

$\mathrm{iFC}$ - indigestible fiber carbohydrates, $\mathrm{g} \mathrm{kg}^{-1} \mathrm{DM}$; $\mathrm{dFC}$ - digestible fiber carbohydrates, $\mathrm{g} \mathrm{kg}^{-1} \mathrm{DM}$; $\mathrm{SGR}$ - specific growth rate of the microorganisms on fraction $\mathrm{dFC}$, $\mathrm{h}^{-1}$; $\mathrm{RD}(\mathrm{dFC})$ - ruminal degradability of $\mathrm{dFC}, \mathrm{g} \mathrm{kg}^{-1} \mathrm{DM}$. 
Table 6 - Mean values for the degradation kinetics of neutral detergent insoluble protein

\begin{tabular}{|c|c|c|c|c|c|c|c|}
\hline \multirow{2}{*}{ Period } & \multicolumn{3}{|c|}{ Treatment } & \multirow{2}{*}{ Equation } & \multicolumn{3}{|c|}{ CI $\left(\beta_{\mathrm{i}}\right) 0.95$} \\
\hline & $\mathrm{T}_{0}$ & $\mathrm{~T}_{40}$ & $\mathrm{~T}_{60}$ & & $\beta_{0}$ & $\beta_{1}$ & $\beta_{2}$ \\
\hline \multicolumn{8}{|l|}{ iNDIP } \\
\hline 1 & $9 a$ & $4 \mathrm{~b}$ & $9 \mathrm{a}$ & $\hat{\mathrm{Y}}=9-0.35 \mathrm{X}+5.8 \times 10^{-3} \mathrm{X}^{2}$ & $(7 ; 11)$ & $(-0.52 ;-0.18)$ & $\left(2.9 \times 10^{-3} ; 8.7 \times 10^{-3}\right)$ \\
\hline 2 & $8 \mathrm{a}$ & $8 \mathrm{a}$ & $9 \mathrm{a}$ & $\hat{Y}=8$ & $(7 ; 10)$ & - & - \\
\hline 3 & $10 \mathrm{a}$ & $10 \mathrm{a}$ & $9 \mathrm{a}$ & $\hat{\mathrm{Y}}=10$ & $(8 ; 11)$ & - & - \\
\hline \multicolumn{8}{|l|}{ dNDIP } \\
\hline 1 & $62 \mathrm{a}$ & $41 \mathrm{a}$ & $52 \mathrm{a}$ & $\hat{\mathrm{Y}}=62-1.23 \mathrm{X}+1.8 \times 10^{-2} \mathrm{X}^{2}$ & $(60 ; 63)$ & $(-1.40 ;-1.06)$ & $\left(1.5 \times 10^{-2} ; 2.1 \times 10^{-2}\right)$ \\
\hline 2 & $20 \mathrm{~b}$ & $23 b$ & $17 b$ & $\hat{Y}=20+0.32 X-6.3 \times 10^{-3} \mathrm{X}^{2}$ & $(18 ; 22)$ & $(0.15 ; 0.50)$ & $\left(-9.2 \times 10^{-3} ;-3.4 \times 10^{-3}\right)$ \\
\hline 3 & $17 \mathrm{~b}$ & $16 \mathrm{c}$ & $16 \mathrm{~b}$ & $\hat{Y}=16$ & $(15 ; 17)$ & - & - \\
\hline \multicolumn{8}{|c|}{$\mathrm{RD}(\mathrm{dNDIP})$} \\
\hline 1 & $41 \mathrm{a}$ & $24 \mathrm{a}$ & $39 a$ & $\hat{Y}=41-1.25 X+2.0 \times 10^{-2} \mathrm{X}^{2}$ & $(39 ; 44)$ & $(-1.48 ;-1.02)$ & $\left(1.6 \times 10^{-2} ; 2.4 \times 10^{-2}\right)$ \\
\hline 2 & $13 b$ & $14 \mathrm{~b}$ & $12 b$ & $\hat{\mathrm{Y}}=13$ & $(12 ; 14)$ & - & - \\
\hline 3 & $10 \mathrm{~b}$ & $9 \mathrm{c}$ & $11 \mathrm{~b}$ & $\hat{\mathrm{Y}}=10$ & $(9 ; 12)$ & - & - \\
\hline
\end{tabular}

Means followed by different letters in the column differ by Tukey's test $(\mathrm{P}<0.05)$.

$\mathrm{T}_{0}$ - pasture only; $\mathrm{T}_{40}$ - supplement with $40 \mathrm{~g}$ rumen undegradable protein per $100 \mathrm{~g}$ of crude protein; $\mathrm{T}_{60}$ - supplement with $60 \mathrm{~g}$ rumen undegradable protein per $100 \mathrm{~g}$ of crude protein; CI - confidence interval.

iNDIP - indigestible neutral detergent insoluble protein, $\mathrm{g} \mathrm{kg}^{-1} \mathrm{DM}$; $\mathrm{dNDIP}$ - digestible neutral detergent insoluble protein, $\mathrm{g}$ kg ${ }^{-1} \mathrm{DM}$; RD( $\left.\mathrm{dNDIP}\right)$ - effective ruminal degradability of digestible neutral detergent insoluble protein, $\mathrm{g} \mathrm{kg}^{-1} \mathrm{DM}$.

\section{Discussion}

The absence of treatment effects on rumen fill corroborates the study of Judkins et al. (1987), who concluded that in steers grazing on pastures with protein contents above $60 \mathrm{~g} \mathrm{~kg}^{-1} \mathrm{DM}$, as observed in this study, protein supplementation does not contributes to alleviate rumen fill. The separation of the rumen-fill effect of each fraction (D and I) according to Waldo et al. (1972), allows for a combined evaluation of the interaction effects of the passage and digestion kinetics on the fiber filling effect at the rumen compartment (Van Soest, 1994; Vieira et al., 2000a,b). Besides, other important quantitative variables in the feeds can be estimated, such as the energy availability and daily amount of metabolizable protein, which enables the prediction of animal performance based on known dietary inputs (Vieira et al., 2000c; Jardim et al., 2013; Jardim et al., 2015; Higgs et al., 2015). In the present study (Table 4), the average RF(I) was approximately $32 \%$ greater than $\mathrm{RF}(\mathrm{D})$, a situation that was also observed by Vieira et al. (2000b) based on extrusa samples taken from a tropical grassland.

In the system proposed by Sniffen et al. (1992), iFC, or simply $\mathrm{C}$, corresponds to the indigestible fiber fraction of the feed corrected for its ash and protein contents, assumed unavailable in the rumen and intestines. This fraction is estimated by the Cornell system by multiplying the amount of lignin by the 2.4 constant (Chandler et al., 1980); in the literature, this value is between 2 and 3 (Van Soest, 1994; Malafaia et al., 1998). However, Vieira et al. (2000b) recommended that estimates of fraction $\mathrm{C}$ may be based on direct biological methods, using, for instance, in situ degradation trials, which compose the methodology relative to the fiber degradation kinetics in the current study. The greater concentration of this fraction in period three may be related to the increased proportions of stems and senescent material. This fact is expected, because as the stage of maturity of tropical grasses advances, the proportion of stems increases, and the latter have a greater cell-wall content, which by its thickening and lignin deposition, tends to increase the indigestible fraction, thereby reducing the potentially digestible fraction.

The increase in fraction $\mathrm{C}$ (Table 5) and the consequent reduction of the NFC imply a reduction of the energy availability for fiber- and non-fiber-carbohydrate-digesting microorganisms, which could affect the microbial synthesis efficiency and lead to nitrogen losses in the rumen if sources of rapid rumen degradation are used (Russell, 2002). Moreover, due to its indigestibility characteristic, this fraction may have an effect on rumen fill, which may limit the dry matter intake in animals with high nutritional requirements (Van Soest, 1994).

In the system proposed by Sniffen et al. (1992), dFC, or $\mathrm{B}_{2}$, corresponds to the potentially degradable fraction of the fiber from the feed corrected for its ash and protein content. This fraction supplies energy more slowly in the rumen, which may affect the microbial synthesis efficiency and the animal performance (Malafaia et al., 1998; 1999). The palisade grass in our study displayed $64 \%$ of its carbohydrates as fraction $\mathrm{B}_{2}$ (Table 5) for periods 1 and 2 , respectively, which is close to the values reported by Velásquez et al. (2010) in natural grassland conditions in the dry and rainy seasons. The supply of protein sources of slow ruminal degradation will provide a greater input of 
amino acids into the small intestine (Cabral et al., 2000), and allow for greater preservation of the consumed nitrogen in relation to other sources that are more rapidly degraded in the rumen. This occurrence was supported by the fact that the main energy contribution of the forages originates from carbohydrate fraction $\mathrm{B}_{2}$ (Malafaia et al., 1998; 1999). This condition will provide the necessary synchronism between nitrogen and energy (from carbohydrates) for microbial protein synthesis (Vieira et al., 2000c; Valkeners et al., 2004; Yang et al., 2010), a situation similar to that found in the present study.

The specific growth rate was not influenced by the treatments. However, differences were detected between periods within each treatment for the experiment. Thus, we observed that SGR showed an association with the effective ruminal degradation of fraction $\mathrm{B}_{2}$. Schofield et al. (1994) and Malafaia et al. (1999) found two specific growth rates of ruminal microorganisms on the potentially degradable fraction of the fiber, allowing us to illustrate the heterogeneous nature of this ingredient (Vieira et al., 2012). Nonetheless, the CNCPS system assumes that fraction $\mathrm{B}_{2}$ is homogeneous and shows a single specific growth rate. Working with natural pastures, Vieira et al. (2000b) found average values of $0.0357 \mathrm{~h}^{-1}$, which was a result close to the estimates obtained in the present study.

Although the palisade grass showed a high $\mathrm{B}_{2}$ fraction ( $64 \%$ of the TC), it had a strong rumen-fill effect (average 11.96 h) (Table 4). Malafaia et al. (1998), working with this forage plant, and Lira et al. (2006), with Urochloa decumbens in the dry season, found 230 and $199 \mathrm{~g} \mathrm{RD}\left(\mathrm{B}_{2}\right)$ $\mathrm{kg}^{-1} \mathrm{DM}$, which are much lower values than the average observed in the current study ( $\left.290 \mathrm{~g} R D\left(\mathrm{~B}_{2}\right) \mathrm{kg}^{-1} \mathrm{DM}\right)$ for the same season of the year. However, in natural-grassland conditions, in the dry season, Vieira et al. (2000b) found a higher value, $301 \mathrm{~g} \mathrm{~kg}^{-1} \mathrm{DM}$. However, the average observed in our experiment (348 $\mathrm{g} \mathrm{RD}\left(\mathrm{B}_{2}\right) \mathrm{kg}^{-1} \mathrm{DM}$ ) was higher than the almost 230-350 $\mathrm{g} \mathrm{kg}^{-1} \mathrm{DM}$ observed in the literature (Malafaia et al., 1998; Vieira et al., 2000b; Lira et al., 2006). This implies that the availability of true protein in the rumen is highly variable and depends on several conditions.

The no-effect of protein supplementation on the NDIP fraction is somewhat consistent with Judkins et al. (1985), because the protein supplements they used presented different degradabilities and enhanced total, soluble, and iNDIP nitrogen, but exerted an inconsistent responsepattern on the dNIP of the diet. In our study, the proportion of fraction C (\% CP) varied from 3 to $13 \%$. In the system proposed by Sniffen et al. (1992), iNDIP corresponds to the rumen- and intestine-indigestible and insoluble protein, composed of proteins bound to lignin by protein- tannin complexes and Maillard artifacts, which are highly resistant to both microbial and host enzymes. These artifact products, despite some controversy, are considered not degradable in the rumen and do not release absorbable amino acids in the small intestine (Michalet-Doreau and Ould-Bah, 1992; Krishnamoorthy et al., 1983). Therefore, this fraction represents the greatest share of the ingested proteins to be excreted in the feces, and according to Van Soest (1994), 5 to $15 \%$ of the total nitrogen from forage plants is bound to lignin, and the values found in the present study lay within this range.

According to Sniffen et al. (1992), dNDIP, or B, corresponds to the insoluble protein with a slow rumendegradation rate, a potential source of amino acids in the small intestine. The palisade grass showed a significant proportion of its nitrogen in the form of slowly-degradable protein, which tends to escape the rumen and supply amino acids to the small intestine. The content of the $\mathrm{B}_{3}$ fraction of this forage plant found in periods two and three (Table 6) is close to the $24 \mathrm{~g} \mathrm{~kg}^{-1} \mathrm{DM}$ found by Malafaia et al. (1997); however, Lira et al. (2006) found only $2 \mathrm{~g} \mathrm{~kg}^{-1} \mathrm{DM}$ after analyzing hand-plucked samples of spreading liverseed grass (Urochloa decumbens (Stapf.) R. Webster) taken during the winter in the Zona da Mata Region of Minas Gerais State, Brazil. Therefore, the variability of this fraction in the pasture is difficult to predict, e.g., Vieira et al. (2000a) analyzed esophageal extrusa samples collected from a natural grassland containing $U$. decumbens and found $11 \mathrm{~g} \mathrm{~kg}^{-1}$ $\mathrm{DM}$ in the dry season and $40 \mathrm{~g} \mathrm{~kg}^{-1} \mathrm{DM}$ in the rainy season. That variability led Higgs et al. (2015) to state that in loco evaluation of the protein fractions of the forage resources is the first strategy to predict animal performance more accurately if the feed library does not contain robust estimates of the feed resources available.

\section{Conclusions}

During the fall in the Cerrado region, supplementation with $40 \mathrm{~g}$ of rumen undegradable protein per $100 \mathrm{~g}$ of crude protein increases the digestible amount of fibrous carbohydrates of the grazed palisade grass. In addition, the lack of a rumen-fill effect demonstrates that the additional supplied protein enhances microbial growth because of a greater turnover as a possible outcome of the resulting larger input of available carbohydrates from the fiber fraction.

\section{Acknowledgments}

T. S. Oliveira thanks Fundação Carlos Chagas Filho de Amparo à Pesquisa do Estado do Rio de Janeiro - FAPERJ 
for the postdoctoral fellowship (case no. E-26/101.429/2014) and Coordenação de Aperfeiçoamento de Pessoal de Nível Superior - CAPES (E-45/2013-PARDPJ). R. A. M. Vieira thanks Conselho Nacional de Desenvolvimento Científico e Tecnológico - CNPq for the grant provided (case no. 304920/2015-0).

\section{References}

AOAC - Association of Official Analytical Chemistry. 1990. Official methods of analysis. 15th ed. AOAC International, Arlington, VA.

Brody, S. 1945. Bioenergetics and growth. With special reference to the efficiency complex in domestic animals. Reinhold Publishing Co., New York.

Cabral, L. D.; Valadares Filho, S. C.; Malafaia, P. A. M.; Lana, R. D.; Silva, J. F. C.; Vieira, R. A. M. and Pereira, E. S. 2000. Protein fractions of tropical feeds and their digestion rate estimated by means of incubation with ruminal protease. Revista Brasileira de Zootecnia 29:2316-2324.

Chandler, J. A.; Jewell, W. J.; Gossett, J. M.; Van Soest, P. J. and Robertson, J. B. 1980. Predicting methane fermentation biodegradability. Biotechnology and Bioengineering Symposium 10:93-107.

Chiou, P. W. S.; Chen, K.; Kuo, K.; Hsu, J. and Yu, B. 1995. Studies on the protein degradabilities of feedstuffs in Taiwan. Animal Feed Science and Technology 55:215-226.

Gao, W.; Chen, A.; Zhang, B.; Kong, P.; Liu, C. and Zhao, J. 2015. Rumen degradability and post-ruminal digestion of dry matter, nitrogen and amino acids of three protein supplements. AsianAustralasian Journal of Animal Sciences 28:485-493.

Gill, J. L. 1986. repeated measurement - Sensitive tests for experiments with few animals. Journal of Animal Science 63:943-954.

Harstad, O. M. and Prestløkken, E. 2001. Rumen degradability and intestinal indigestibility of individual amino acids in corn gluten meal, canola meal and fish meal determined in situ. Animal Feed Science and Technology 94:127-135.

Hentz, F.; Kozloski, G. V.; Orlandi, T.; Ávila, S. C.; Castagnino, P. S.; Stefanello, C. M. and Pacheco, G. F. E. 2012. Intake and digestion by wethers fed a tropical grass-based diet supplemented with increasing levels of canola meal. Livestock Science 7:89-95.

Higgs, R. J.; Chase, L. E.; Ross, D. A. and Van Amburgh, M. E. 2015. Updating the Cornell net carbohydrate and protein system feed library and analyzing model sensitivity to feed inputs. Journal of Animal Science 98:6340-6360.

Jardim, J. G.; Vieira, R. A. M.; Fernandes, A. M.; Araujo, R. P.; Glória, L. S.; Rohem Júnior, N. M.; Rocha, N. S. and Abreu, M. L. C. 2013. Application of a nonlinear optimization tool to balance diets with constant metabolizability. Livestock Science 158:106-117.

Jardim, J. G.; Vieira, R. A. M.; Fernandes, A. M.; Araujo, R. P.; Glória, L. S.; Rohem Júnior, N. M.; Rocha, N. S. and Abreu, M. L. C. 2015. Corrigendum to "Application of a nonlinear optimization tool to balance diets with constant metabolizability". Livestock Science 173:119-120

Judkins, M. B.; Krysl, L. J.; Wallace, J. D.; Galyean, M. L.; Jones, K. D. and Parker, E. E. 1985. Intake and diet selection by protein supplemented grazing steers. Journal of Range Management 38:210-214.

Judkins, M. B.; Wallace, J. D.; Galyean, M. L.; Krysl, L. J. and Parker, E. E. 1987. Passage rates, rumen fermentation, and weight change in protein supplemented grazing cattle. Journal of Range Management 40:100-105.
Kleiber, M. 1975. The fire of life. An introduction to animal energetics. Robert E. Krieger Publishing Co., Inc., New York.

Kottek, M.; Grieser, J.; Beck, C.; Rudolf, B. and Rubel, F. 2006. World Map of the Köppen-Geiger climate classification updated. Meteorologische Zeitschrift 15:259-263.

Krishnamoorthy, U.; Sniffen, C. J.; Stern, M. D. and Van Soest, P. J. 1983. Evaluation of a mathematical model of rumen digestion and an in vitro simulation of rumen proteolysis to estimate the rumen-undegraded nitrogen content of feedstuffs. British Journal of Nutrition 50:555-568.

Licitra, G.; Hernandez, T. M. and Van Soest, P. J. 1996. Standardization of procedures for nitrogen fractionation of ruminant feeds. Animal Feed Science and Technology 57:347-358.

Lira, V. M. C.; Pereira, J. C.; Vieira, R. A. M.; Henrique, D. S. and Leonel, F. P. 2006. Avaliação de marcadores e modelos matemáticos para o estudo das cinéticas de trânsito e de degradação ruminal em novilhos mantidos em pastagem de capim-braquiária (Brachiaria decumbens Stapf.). Revista Brasileira de Zootecnia 35:902-913.

Malafaia, P. A. M.; Valadares Filho, S. C. and Vieira, R. A. M. 1997. Determinação e cinética ruminal das frações proteicas de alguns alimentos para ruminantes. Revista Brasileira de Zootecnia 26:1243-1251

Malafaia, P. A. M.; Valadares Filho, S. C.; Vieira, R. A. M.; Silva, J. F. C. and Pereira, J. C. 1998. Determinação das frações que constituem os carboidratos totais e da cinética ruminal da fibra em detergente neutro de alguns alimentos para ruminantes. Revista Brasileira de Zootecnia 27:790-796.

Malafaia, P. A. M.; Valadares Filho, S. C. V. and Vieira, R. A. M. 1999. Kinetic parameters of ruminal degradation estimated with a non-automated system to measure gas production. Livestock Production Science 58:65-73.

Michalet-Doreau, B. and Ould-Bah, M. Y. 1992. Influence of hay making on in situ nitrogen degradability of forages in cows. Journal of Dairy Science 75:782-788.

Miranda, L. F.; Rodriguez, N. M.; Pereira, E. S.; Queiroz, A. C.; Sainz, R. D.; Pimentel, P. G. and Gontijo Neto, M. M. 2012. Chemical composition and ruminal degradation kinetics of crude protein and amino acids, and intestinal digestibility of amino acids from tropical forages. Revista Brasileira de Zootecnia 41:717-725.

Nocek, J. E. 1988. In situ and other methods to estimate ruminal protein and energy digestibility: a review. Journal of Dairy Science 71:2051-2069

Oliveira, I. P.; Kluthcouski, J.; Yokoyama, L. P.; Dutra, L. G.; Portes, T. A.; Silva, A. E.; Pinheiro, B. S.; Ferreira, E.; Castro, E. M. and Guimaraes, C. M. 1996. Sistema Barreirão: recuperação/ renovação de pastagens degradadas em consórcio com culturas anuais. EMBRAPA-CNPAF, Goiânia.

Pereira, J. C.; Ribeiro, M. D.; Vieira, R. A. M. and Pacheco, B. M. 2005. Avaliação de modelos matemáticos para o estudo da cinética de passagem de partículas e de fluidos por bovinos em pastagem recebendo suplementos contendo diferentes níveis de proteína não-degradável no rúmen. Revista Brasileira de Zootecnia 34:2475-2485.

Pond, K. R.; Ellis, W. C.; Matis, J. H.; Ferreiro, H. M. and Sutton, J. D. 1988. Compartment models for estimating attributes of digesta flow in cattle. British Journal of Nutrition 60:571-595.

Russell, J. B. 2002. Rumen microbiology and its role in ruminant nutrition. James B. Russell ${ }^{\circ}$, Ithaca.

Satterthwaite, F. E. 1946. An approximate distribution of estimates of variance components. Biometrics Bulletin 2:110-114.

Scales, G. H.; Streeter, C. L.; Denham, A. H. and Ward, G. M. 1974. Effect of mastication, salivary contamination and leaching on the chemical composition of forage samples collected via esophageal fistulae. Journal of Animal Science 38:1278-1283. 
Schofield, P.; Pitt, R. E. and Pell, A. N. 1994. Kinetics of fiber digestion from in vitro gas production. Journal of Animal Science 72:2980-2991.

Sniffen, C. J.; O'Connor, J. D.; Van Soest, P. J.; Fox, D. G. and Russell, J. B. 1992. A net carbohydrate and protein system for evaluating cattle diets: II. Carbohydrate and protein availability. Journal of Animal Science 70:3562-3577.

Udén, P.; Colucci, P. E. and Van Soest, P. J. 1980. Investigation of chromium, cerium and cobalt as markers in digesta. Rate of passage studies. Journal of the Science of Food and Agriculture 31:625-632.

Valkeners, D.; Thewis, A.; Piron, F. and Beckers, Y. 2004. Effect of imbalance between energy and nitrogen supplies on microbial protein synthesis and nitrogen metabolism in growing double-muscled Belgian Blue bulls. Journal of Animal Science 82:1818-1825.

Van Milgen, J.; Murphy, M. R. and Berger, L. L. 1991. A compartmental model to analyze ruminal digestion. Journal Dairy Science 74:2515-2529.

Van Soest, P. J. 1994. Nutritional ecology of the ruminant. Cornell University Press, Ithaca.

Van Soest, P. J.; Robertson, J. B. and Lewis, B. A. 1991. Methods for dietary fiber, neutral detergent fiber, and nonstarch polysaccharides in relation to animal nutrition. Journal of Dairy Science 74:3583-3597.

Velásquez, P. A. T.; Berchielli, T. T.; Reis, R. A.; Rivera, A. R.; Dian, P. H. M. and Teixeira, I. A. M. A. 2010. Composição química, fracionamento de carboidratos e proteínas e digestibilidade in vitro de forrageiras tropicais em diferentes idades de corte. Revista Brasileira de Zootecnia 39:1206-1213.

Vieira, R. A. M.; Campos, P. R. S. S.; Silva, J. F. C.; Tedeschi, L. O. and Tamy, W. P. 2012. Heterogeneity of the digestible insoluble fiber of selected forages in situ. Animal Feed Science and Technology 171:154-166.

Vieira, R. A. M.; Pereira, J. C.; Malafaia, P. A. M. and Queiroz, A. C. 1997. The influence of elephant-grass (Pennisetum purpureum Schum., Mineiro variety) growth on the nutrient kinetics in the rumen. Animal Feed Science and Technology 67:151-161.

Vieira, R. A. M.; Pereira, J. C.; Malafaia, P. A. M.; Queiroz, A. C. and Gonçalves, A. L. 2000a. Fracionamento e cinética de degradação in vitro dos compostos nitrogenados da extrusa de bovinos a pasto. Revista Brasileira de Zootecnia 29:880-888.

Vieira, R. A. M.; Pereira, J. C.; Malafaia, P. A. M.; Queiroz, A. C. and Gonçalves, A. L. 2000b. Fracionamento dos carboidratos e cinética de degradação in vitro da fibra em detergente neutro da extrusa de bovinos a pasto. Revista Brasileira de Zootecnia 29:889-897.

Vieira, R. A. M.; Pereira, J. C.; Malafaia, P. A. M.; Queiroz, A. C.; Jordão, C. P. and Goncalves, A. L. 2000c. Simulation of the nutrient dynamics in the gastrointestinal tract: application and validation of a mathematical model for grazing cattle. Revista Brasileira de Zootecnia 29:898-909.

Waldo, D. R.; Smith, L. W. and Cox, E. L. 1972. Model of cellulose disappearance from the rumen. Journal of Dairy Science 55:125-129.

Wilson, J. R. 1994. Cell-wall characteristics in relation to forage digestion by ruminants. Journal of Agricultural Science 122:173-182.

Wilson, J. R. and Mertens, D. R. 1995. Cell-wall accessibility and cell structure limitations to microbial digestion of forage. Crop Science 35:251-259.

Yang, J. Y.; Seo, J.; Kim, H. J.; Seo, S. and Ha, J. K. 2010. Nutrient Synchrony: Is it a suitable strategy to improve nitrogen utilization and animal performance? Asian-Australasian Journal of Animal Sciences 23:972-979. 


\section{ERRATUM}

In the article "Kinetics of digestion of low-quality forage grazed by beef cattle fed supplements containing increasing levels of rumen undegradable protein", published in Revista Brasileira de Zootecnia, 45(9):563-571, 2016, on page 563, where it reads:

"Flavio Henrique Vidal Alfredo"

it should read:

"Flavio Henrique Vidal Azevedo" 